\title{
Study on Depth Fusion Practice Mechanism between Enterprises and Colleges in Interior Interior design Specialty
}

\author{
Wu Yi and TAN Jie \\ ChongQing Technology And Business Institute 400052 \\ Yanching Institute of Technology 065201
}

Keywords: Interior design Specialty, depth fusion between enterprises and schools, practice teaching.

\begin{abstract}
Practice teaching plays a crucial role in cultivating applied talents in higher schools, in view of the problems about the practice teaching pattern is single, the effect was not significant, and the shortage of practice education resources in current higher schools, this paper analyzes the necessity of strengthening the cooperation between schools and enterprises to improve the effect of practice teaching, and puts forward the approaches to realize depth integration between schools and enterprises of Interior design Specialty, even improving the quality of practical teaching, cooperation to complete the major projects; building a practice platform, to improve the practical ability of students; balancing the interests of all parties, to realize the tripartite win-win.
\end{abstract}

\section{Introduction}

Design Specialty is introduced in the 1980s of the modern design education system in higher schools. The graduates can be engaged in interior design, gardening design, architectural design, and closely connected with people's daily life, so there are broad prospects for development[1]. At present many colleges and universities oriented by employment,and school enterprise cooperation in personnel training mode has become the main mode of teaching. In fact, school enterprise cooperation mode is diversified,not only have the college and enterprise joint school running, run enterprises, and universities provide order type education for enterprises. However, we need to pay attention to the process of cooperation in the past, for there ware borrowed cooperation method in developed countries in the cooperation between Design professional and business .Due to the lack of localization and innovation of school enterprise cooperation, there is leading to a series of problems. Therefore, in order to obtain a broader space for development, and eventually realize the maximum utilization and benefit sharing of educational resources, the colleges and universities must get a clear understanding of the development of Interior design Specialty, and on this basis, discuss on the development path of design integration of professional school enterprise depth, in order to design professional development to provide more vast space, finally realize the maximum utilization and benefit sharing of educational resources.

\section{Development situation of the practice teaching about the Interior design Specialty}

\subsection{The practice teaching mode is single, and teaching effect is not obvious}

In terms of the higher schools Interior design Specialty, due to the particularity of the specialty, only the 
advanced teaching mode will make the further development. However, from the present development situation, the teaching mode is more traditional, and the teaching effect is not obvious enough. The teaching mode has limited students' thinking of creativity[3]. In the process of the closed teaching, students who major in Interior design Specialty will lose those interest of learning unconsciously, they cannot contact curriculum and practice together effectively, which greatly limits students' creative passion. In terms of the students who major in Interior design Specialty, there will not be a long-term development inevitably if they don't have innovative works.

In the traditional teaching mode, classroom teaching and practical teaching is separated, the teaching of higher schools mostly based theory, and the teaching content is also confined to the basic knowledge teaching, rarely related to practice teaching. Thus, the students will have the impression of "priority to theory and minor attention to practice", which will be not conducive to the future work and practice.

\subsection{Practice teaching concept needs innovation, curriculum system is relatively single}

Higher schools Interior design Specialty includes the extensive category, which partly requires that the designers must be familiar with production process of design, and develop their own capacity of design and space shape. It should be said that, teaching concept directly affects the quality of teaching, Advanced teaching concept has an important role in promoting the quality of teaching, and relatively backward teaching concept directly affects the completeness and integrity of teaching system to a certain extent.

At present, the higher schools are mostly in accordance with the ordinary institutions of higher learning to set up the course of curriculum system, can't according to the current situation of the development to position, deviate from the actual development direction of employment. At the same time, the content of the course is very imbalance, and Interior design Specialty has stronger practice, this kind of practice is not an overnight process, which needs students continuously grope and discussion[4]. At present, judging from the contents of the courses in our higher schools, the contents of the theory and practice are serious imbalance, will not be able to meet the demand of the students' reality (figure 1).

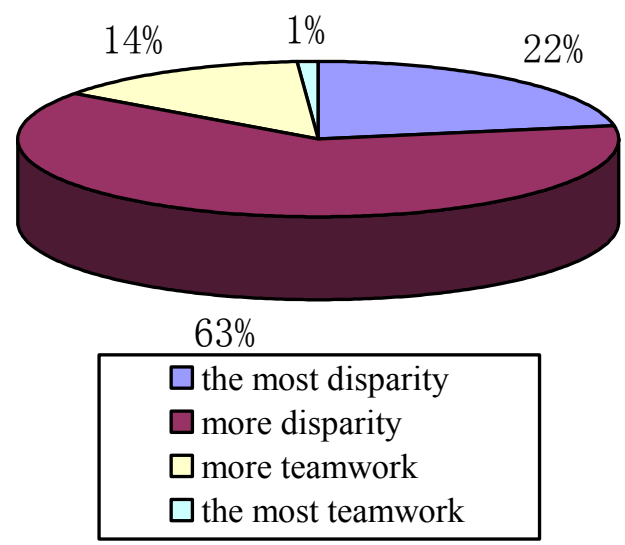

Fig 1: The results of the survey for the gap between a higher schools course and the actual demand

\subsection{The relative lack of the practice teaching resources, the development of education lose guarantee}

First of all, the resources of higher schools Interior design Specialty in our country are relatively lack, and the resources also can't meet the current diversification needs of teaching. From the point of view of the hardware facilities, the education resources is only confined to the computer room and the classroom of drawing, the 
necessary laboratory resources has not been universal developed, which has a directly impact on the students' ability of design and practice ability[5].

Secondly, the teachers resources of higher schools Interior design Specialty in our country are limited, lacking of elite teachers' team. From table 1we can see that the survey results of teachers structure in higher schools of environmental art Interior design Specialty in ningxia province, that is to say, not only the overall population of teachers is less, but also teachers' age structure is distribution and smaller; The structure of professional titles is Internationale, lacking of professor level teachers; Teachers' educational structure is also unreasonable..

Table 1: the survey results of teachers structure in higher schools of environmental art Interior design Specialty in ningxia province

\begin{tabular}{|c|c|c|c|}
\hline \multirow{2}{*}{ Age structure } & Under the age of 35 & The age of between 35and45 & Over the age of 45 \\
\cline { 2 - 4 } & 12 & 4 & 3 \\
\hline \multirow{2}{*}{ Professional structure } & Assistant & lecturer & Professor \\
\cline { 2 - 4 } & 4 & 12 & 3 \\
\hline \multirow{2}{*}{ Educational structure } & Undergraduate and the following & Master & Doctor \\
\cline { 2 - 4 } & 10 & 9 & 0 \\
\hline
\end{tabular}

\section{The necessary of depth fusion of Interior design Specialty}

\subsection{Good relations of schools enterprise cooperation is the basic condition of course construction}

First of all, establish a good relationship of interactive and cooperation, and make full use of the experience. Through the cooperation with enterprises, the universities can introduce the resources of the interior Design Company, in order to reach the depth of cooperation of school and enterprise.For example, the universities can use the cases of the Interior Design Company as the practice of university teaching material, in order to make the school practice teaching material can keep pace with the social needs of customers and the aesthetic tendency. Secondly, establish the cooperation mechanism between schools and enterprises, so as to solve many problems in school-enterprise cooperation. Interior design professional teachers in general lack of practical experience, in the interior design sector, laying of water pipes and circuit design has many requirements and tips. With the way of common construction course to make professor go to school to have a class on a regular basis, at the same time school also examine and examine the courses on a regular basis, to ensure that the smooth cooperation between schools and enterprises.

\subsection{School enterprise cooperation to achieve diversified innovation of Interior design Specialty}

First of all, the curriculum system is needed more scientific. For the higher schools Interior design Specialty, to reform curriculum system has been one of the important problems faced by higher schools, through school enterprise cooperation mode, the courses of higher schools Interior design Specialty have become more scientific, that is to say, the curriculum system of higher schools is no longer blindly copying other college courses, but based on the development characteristics of the higher schools, highlight the characteristics of employment oriented.

Secondly, through school enterprise cooperation the course has been common development. For the higher schools Interior design Specialty, the development of school enterprise cooperation is a complicated project. 
Enterprise integration in education can design creative education mode, whether textbook design or curriculum, diversity can achieve efficient in the interior design specialty teaching.

\subsection{School enterprise cooperation is indispensable to alleviate employment pressure}

First of all, the employment pressure forced the higher schools to walk the road of school enterprise cooperation. For college students, because of their knowledge accomplishment and ordinary college students have a certain gap, so by improving the ability of practice ways on employment of the road is a good choice. It should be said, in the environmental full of competition pressure, which is a kind of pressure for schools, enterprises, students, meanwhile which is also a kind of power.

Secondly, school enterprise cooperation, let employment channels more diversified. Compared with the traditional type of employment, school enterprise cooperation can give students more employment chance, and the employment time is more early, students do not have to worry about the situation of delay graduation, that is to say, during the practice of enterprises, students have been found good jobs for themselves, greatly improving the rate of employment, and also make the way of employment more diversified.

\section{Path of the depth integration for higher schools Interior design Specialty}

\subsection{Improving the quality of practical teaching, cooperation to complete the major projects}

Teaching is the basis of education development, which occupies the important status in society in the process of higher schools education, and teachers' education level directly influences on the quality of practice teaching to a certain extent. For higher schools Interior design Specialty, the improvement of teachers' quality helps to improve the practice teaching quality.

First of all, the school should encourage the teachers to understand the actual operation into the Interior Design Company,to improve their ability of teaching practice. From the knowledge perspective, higher schools Interior design Specialty not only requires a deep knowledge of art, but also need to practice ability. Therefore, higher schools Interior design Specialty teachers need to continue to participate in practice and teaching at the sharp end, through the way to improve their teaching level unceasingly.

At the same time, the school should continue to encourage teachers and enterprise cooperation, and participate in the development and design of the Interior Design Company's project. Teachers should actively participate in developing and designing of enterprise projects, to improve the teachers' professional practice skills, at the same time organizing teachers to the relevant factory to investigation and study, to accumulate professional experience, then change these practice experience into valuable theoretical knowledge to teach students.

Finally, teachers should be guided by the market, looking for employment opportunities for students. Teachers should always pay attention to the development dynamic of higher schools Interior design Specialty, and timely access to the latest market information, so as to apply the most advanced design concepts of teaching. At the same time, in the teaching process teachers should to pay close attention to the employment trends of higher schools Interior design Specialty, in cooperation with the enterprises, to strive for more jobs for students

\subsection{Building a practice platform, to improve the practical ability of students}

School enterprise cooperation provides a practice platform for students, and this practice platform for the students who major in design professional in higher schools is critical, it should be said, to build learning and practicing platform for students is very significance. First of all, schools should establish the Interior design 
practice base in the enterprise. The practice ability of student who major in design professional in higher schools is directly related to the employment ability, therefore, it is necessary to use the resources of the enterprise for setting up practice base in university, which is adapt to the inevitable trend of social development.

The higher schools establish the practice base in enterprises, on the one hand, can help the students have the opportunity of practicing in enterprise and becoming a stylist, on the other hand, students can improve their practice ability by means of practice, and accumulate more experience in practice. Secondly, through schools enterprise cooperation mode, enterprises should establish a special talents training center. Through the expansion of the scale, enterprises can provide a platform of employment opportunities for college students, establish an integration of the training center, help the students walk into the enterprises and become a member of the enterprises.

\subsection{Balancing the interests of all parties, to realize the tripartite win-win}

Higher schools and enterprises is an important relies on student's employment, through school enterprise cooperation way, not only to maximize the realization of the tripartite win-win, but also to adapt to the trend of development of social market economy. To achieve mutual fusion three and win-win situation between higher schools and the enterprise, we must do the following two points.

First of all, improve the relevant system, maintain the three rights. In the system arrangement, the school should be based on students' interests as the fundamental starting point, formulate a scientific and reasonable system, to maximize the maintenance of the interests of students; students should to sign contract with the practical business, In the maintenance of their own interests but also to maintain the maximum benefit of the school; the enterprises should take the development as a starting point, sign the relevant contracts with universities and students, abide by the rule of the market and optimize the internal management of enterprise, so as to realize the benefit maximization.

Secondly, the higher schools and the enterprise should to abide by the principle of cooperation; enhance the consciousness of the overall situation. That is to say, the higher schools design specialized and related enterprises should to establish the principle of equality and mutual benefit, cooperation and win-win. Based on the social development situation, higher schools and enterprises should to proceed from the whole perspective of interests, coordinate the relationship between design theory and practice, so as to realize the depth fusion of higher schools Interior design Specialty.

\section{References}

[1] Oliver W.Cummings.Cooperation between business and education to meet the challenge of a changing environment. 2008.

[2] Liu De-qiang. Systematic Thinking on Speeding up Higher Vocational Enterprise-school Cooperation Legislation. Vocational Education Research, vol.1, pp. 97-99, 2011.

[3] Xing Ju, Zhao Jing. Analysis on Problems and Solutions of the Current Policies about Enterprise-school Cooperation. China Education Innovation Herald, vol.29, pp.56-57, 2011.

[4] Han Tan-xue. Under the in-depth cooperation between colleges and enterprises the exploration and practice of teaching quality in Higher Vocational Education. Chinese Vocational and Technical Education. vol 20, pp.53-55+60,2012.

[5]Liu Yi-lun,Liu Tie-xiong. In the reform of engineering education to urge the in-depth cooperation between colleges and enterprises [J]. China Higher Education.vol 06 ,pp.22-24,2011. 